\title{
Electrodeposition of Zinc from Galvanized Steel
}

\author{
Ruqia Hisham Abd ulster Rabiha Salih Yaseen $\quad$ Firas Farhan Sayyid
}

Department of Production Engineering and metallurgy, University of Technology, BaghdadIraq

qanoonyhisham@yahoo.com

\begin{tabular}{|l|l|l|}
\hline Submission date:- 7/2/2019 & Acceptance date:- 24/3/2019 & Publication date:-7/4/2019 \\
\hline
\end{tabular}

\begin{abstract}
In this work, the effect of voltage and concentration on the properties of zinc powder (purity, morphology, and apparent density) that produced by electrodeposition process from industrial waste (galvanized steel) was studied. In Electrodeposition process, used sulfuric acid $\mathrm{H}_{2} \mathrm{SO}_{4}$ with concentration $0.2 \mathrm{M}$ and zinc sulphate heptahydrate $\mathrm{ZnSO}_{4} .7 \mathrm{H}_{2} \mathrm{O}$ in three different concentrations $(100,75$, and 50) $\mathrm{M}$, The time of deposition is $10 \mathrm{mins}$, three electrodes were used, the distance between electrodes was $3 \mathrm{~cm}$ for all experiments and the $\mathrm{PH}$ of solutions were $0.3,0.4,0.6$ for three concentrations respectively. The voltages that used were $(2,3,4,6,8$, and11) V. First of all, the morphology of zinc powder for all experiments was dendritic. The effect of voltage on the apparent density in ranging was from 1.2 to $0.71 \mathrm{gm} . / \mathrm{cm}^{3}$ in $100 \mathrm{M}$ for voltages from $2 \mathrm{~V}$ to $11 \mathrm{~V}$, it was from 0.94 to $0.60 \mathrm{gm} . / \mathrm{cm}^{3}$ in $75 \mathrm{M}$, and it was from 0.80 to $0.50 \mathrm{gm} . / \mathrm{cm}^{3}$ in $50 \mathrm{M}$ concentration. The purities increased with decrease of zinc ion concentration were $(89.51,92.78$, and 95.48) for three different concentrations of same voltage $2 \mathrm{~V}$. The highest purity of $\mathrm{Zn}$ powder was 95.58 in $6 \mathrm{~V}$ in $50 \mathrm{M}$ concentration.
\end{abstract}

Keywords: Zinc, galvanized steel, Electrodeposition process, Sulfuric acid, Purity, and Apparent density.

\section{Introduction}

Zinc is a significant base metal used in different industries like; metallurgical industry, chemical industry and textile industry [1]. Zinc metal is never found pure in nature; the primary source of zinc is from sphalerite, hemimorphite, hydrozincite, calamine, franklinite, smithsonite, willemite, and zincite [2]. Some of zinc was recovery from various secondaries like: galvanizing, flue dust of electric arc furnace and brass smelting, smelting, zinc dross, zinc ash, scrap recycling, casting, and automobile shredder scrap. Zinc existent in secondary resources in metallic form, oxides form, and alloy form. And it is related to various levels of impurities that depend on its sources [3]. To recover metallic values the materials could be used, or these materials can be disposed of. But, the disposals-off (materials) are now become expensive due to; increasing extent strict environmental protection laws [4]. Dust particles have a chemical nature like that these are defined as hazardous wastes. Toxicity was fundamentally done because of the presence of different metals like; cadmium metal, lead metal, arsenic, and chromium metal, there was an increase benefit in developing process to zinc recovery from secondaries/waste [5]. The process must produce a scrap which can be recycled with more processing or disposed -off significantly without effect on the environment. Commonly, pyro-metallurgical and hydro-metallurgical processes were utilized to treat secondaries [6]. The main obstacle of the pyro-metallurgical method is; necessity of high energy, and dust collecting/gas cleaning system required. The salts of chloride and fluoride that present in the dust cause difficult corrosion problems and necessitate using expensive alloys like materials of construction. The hydro-metallurgical process is more friends to environments; it is appropriate and economical to the treat of low zinc containing materials with small scale. It could process secondaries containing various impurities. Usually can use various lixiviates such as sulpharic acid, ammonia/ammonium carbonate, hydrochloric acid, ammonium chloride, caustic soda, and carboxylic acid, are used for recovery of zinc[3]. Zinc is found in the air, soil, and water and is present in all foods. In its pure elemental (or metallic) form, a common use for zinc is to coat steel and iron (galvanization) to prevent rust and corrosion this is because the open circuit potential of zinc is lower than that of steel. Metallic zinc is also mixed with other metals to form alloys such as brass and bronze, it is also used to make dry cell batteries $[7,8]$. 
Zinc is recycled from end-of-life products such as: brass and zinc die-cast alloys, galvanized steel, zinc sheet products, industrial chemicals utilizing zinc oxide and other zinc derivatives, electroplating and metal spraying processes, and The motor industry, where a number of automobile parts are made from die-cast zinc alloys containing a high percentage of zinc [9, 10]. Electrodeposition is a stable technique, used for depositing coatings at beginning. The metal ions present in the solution are forced by electric current, to be coated on cathode. It is a very cheap method [11]. This process refers to a film growth process, which composed in the formation of a metallic coating or powders by electrochemical reduction of the metal ions from the electrolyte onto a base material [12]. Metal powders produced by electrodeposition process of aqueous solutions and fused salts [13]. This method is opposite of electroplating that hard and brittle mass are deposited, these masses are subsequently ground to powders have dendritic shapes [14]. The electrodeposition process is done by the immersion of the plate in a container involving the electrolyte and two electrodes, followed by pass the current through the device by linked the electrodes with external power supply [15].

There was a lot of literature reviews about produced zinc powder from electrodeposition process like as:

- Electrodeposition and dissolution of zinc in sulfuric acid were studied as the negative electrode reactions in acidic zinc-based redox flow batteries. The zinc deposition and dissolution is a quasireversible reaction with a zinc ion diffusion coefficient of $4.6910-6 \mathrm{~cm} 2 \mathrm{~s}-1$ obtained. The increase of acid concentration facilitates an improvement in the kinetics of zinc electrodepositiondissolution process. But too high acid concentration would result in a significant decrease in charge efficiency [16].

- Galvanized steel was used to recovery Zn by using sulfuric acidic solutions with pH value up to 0.2. A that this solution was containing Zn over 80-85 g/l and Fe $0.2 \mathrm{~g} / \mathrm{l}$ can be produced by repeated stripping, the precipitated $\mathrm{Zn}$ compound is $\mathrm{ZnSO} 4 . \mathrm{H} 2 \mathrm{O}$. This compound contains $36.4 \% \mathrm{Zn}$ and $0.002 \% \mathrm{Fe}$ and is a raw material pure enough for commercial use. The ethyl alcohol used to obtain $\mathrm{ZnSO} 4 . \mathrm{H} 2 \mathrm{O}$ from the rich stripping solution is recovered with $90 \%$ efficiency through distillation at $78^{\circ} \mathrm{C}$ for $20 \mathrm{~min}$. This process optimized by the experiments allows for the manufacture of saleable products and causes no environmental problems [17].

The aim of this work is study the effect of change in voltages and concentrations on the properties of zinc powder.

\section{Experimental work (the materials and methods)}

The scrap material used in this process is galvanized steel. Beginning cut the water tank (galvanized steel) into pieces in dimensions $4 \mathrm{~cm}$ as width and $8 \mathrm{~cm}$ as length the cut process is done by mechanical cutter, The XRF analyses (AMETEK 2010, Germany) of these materials are shown in Table (1-1). The analysis was conducted at German-Iraqi laboratory, Geological Department, College of Sciences/ University of Baghdad.

Table (1-1): XRF analysis of galvanized steel

\begin{tabular}{|l|c|}
\hline \multicolumn{1}{|c|}{ Continent } & \% Percentages \\
\hline $\mathrm{Zn}$ & 69.77 \\
\hline $\mathrm{Fe}$ & 15.20 \\
\hline $\mathrm{Al}$ & 5.607 \\
\hline $\mathrm{S}$ & 8.924 \\
\hline $\mathrm{Pb}$ & 0.06180 \\
\hline $\mathrm{K}$ & 0.3624 \\
\hline $\mathrm{Ca}$ & 0.9513 \\
\hline $\mathrm{Si}$ & 11.82 \\
\hline $\mathrm{Mn}$ & 0.0189 \\
\hline
\end{tabular}

\subsection{Electrodeposition process:}

In this electrodeposition process three electrodes used two as anode and one as cathode, used galvanized steel as anode and stainless steel as cathode, The voltages that used in this study with six 
different values $(2,3,4,6,8$ and 11) $\mathrm{V}$, the time of deposition was constant in all experiments about 10 $\min$ and the temperature also constant, it was in temperature room $25^{\circ} \mathrm{c}$.The procedure of electrodeposition of zinc was shown below in flow chart figure 1. In this process two anodes with effective area $16 \mathrm{~cm}^{2}$ and one cathode with effective area $32 \mathrm{~cm}^{2}$ were used. The three electrodes immersed in the cell in vertically parallel state and linked with power supply by wires cathode in the middle and two anodes set in the external side of cathode as shown in the figure 2 . The device that used is container Pyrex glass in rectangular shape with dimensions $(25,12.5$, and 7$) \mathrm{cm}$ as length, width and height respectively. And used power supply as shown in figure 3 with voltages in range $10 \mathrm{~A}$ and (0-50) $\mathrm{V}$, Direct current (DC) supplier was attached with the galvanized steel specimen to the positive side, while the negative side was connected with stainless steel electrode as shown in figure 3

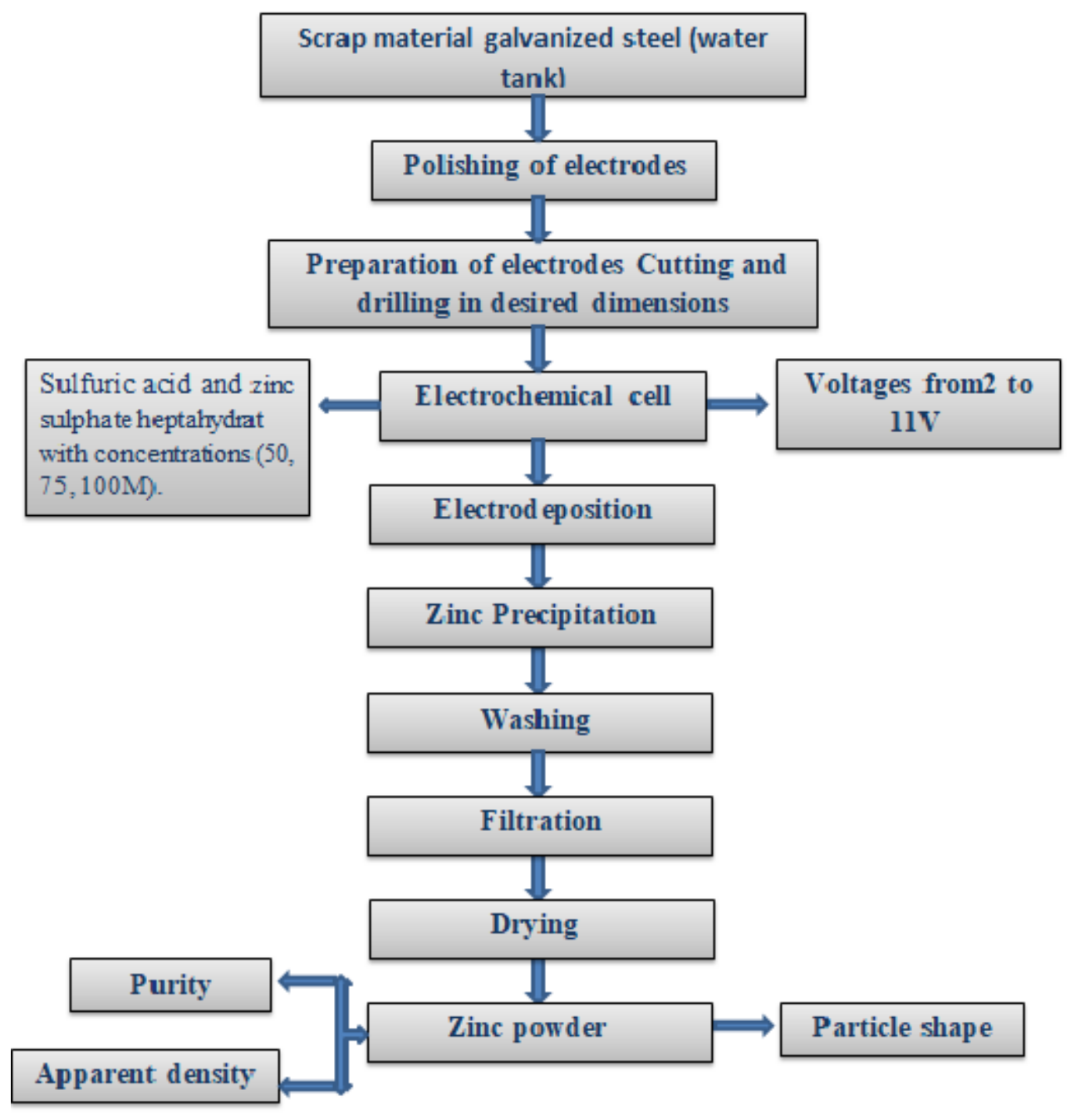

Figure1: flow chart for the experiments carried out for the electrodeposition of zinc from galvanized scraps. 


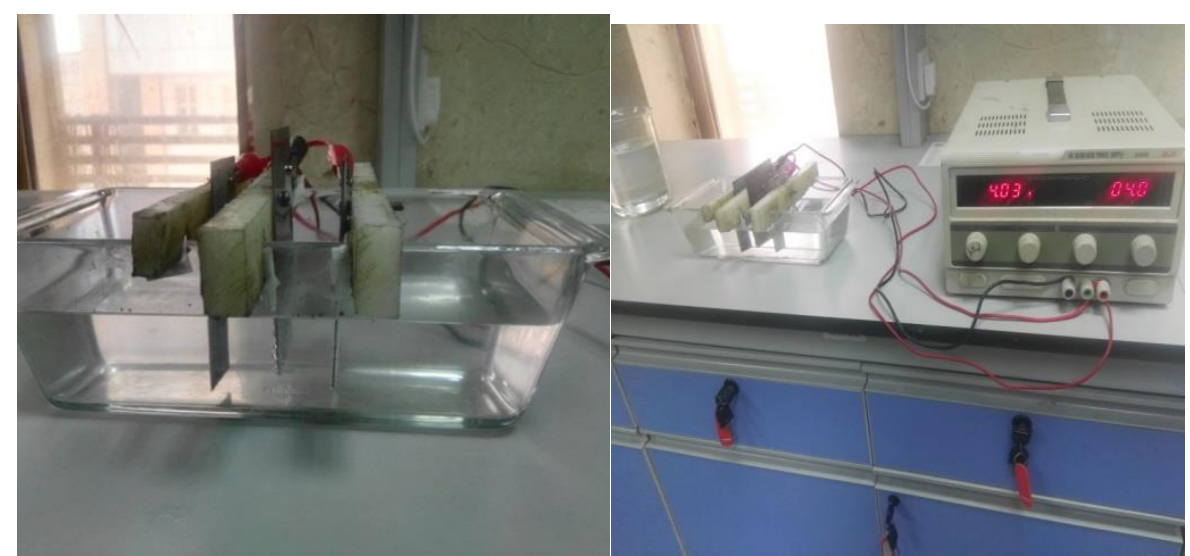

Figure 2 shows the electrodeposition

\section{Process of zinc.}

figure 3 shows the device used in

\section{Electrodeposition process.}

\subsection{The electrolyte solution:}

The electrolyte solution is a mixture from dilute sulfuric acid in concentration $0.2 \mathrm{gm} / \mathrm{L}$ and zinc sulphate heptahydrate in different concentrations $(50,75$ and 100) gm. /L, they are dissolved in (1000 $\mathrm{ml}$ ) distilled water by continues agitation with a magnetic stirrer, it was left until temperature of solution reached room temperature, after that, the solution was used in electrodeposition cell [18]

\subsection{Cathode washing process:}

The washing process is done by used deionized water, sodium tartrate, and sodium carbonate. Firstly, wash cathode electrode by deionized water, secondly washed it by sodium tartrate to remove the remain acid that relate with cathode, washed by deionized water again to remove the remaining sodium tartrate and after that impressed the cathode in sodium carbonate to remove the impurities, lastly washed cathode by deionized water to remove the remaining sodium carbonate and at this stage the cathode scrape by scraper tool to remove the powder as shown in figure 4 and after that filtering the deionized water that contain the powder by using vacuum filter that shown in figure 5 , and dried it in $100^{\circ} \mathrm{C}$, in every time the washing process take $5 \mathrm{~min}$ with moving the cathode slowly in solution.

\subsection{Apparent density}

To estimate the apparent density, the powder was poured into an empty bowl, whose size is known as the weight of the empty container as well as the weight, which is filled with powders, the apparent density is calculated from equation 1.1

$\rho=\left(w_{-} 2-w_{-} 1\right) / v-p$

$\mathrm{w} 1=$ where an empty vessel weight $\mathrm{gm}$.

$\mathrm{W} 2=$ where filled with the weight of the container gm.

$\mathrm{V}-\mathrm{p}=$ powder volume $\mathrm{cm} 3$.

$\rho=$ apparent density $\mathrm{gm} / \mathrm{cm} 3$.

\subsection{X-Ray fluorescence analysis}

The purity of zinc powder was carried out by using X-ray fluorescence-XRF (AMETEK 2010, Germany). The analysis was conducted at German-Iraqi laboratory, Geological Department, College of Sciences/ University of Baghdad.

\section{Results}

Experiments of $\mathrm{Zn}$ electrodeposition with $\mathrm{H}_{2} \mathrm{SO}_{4}$

Figure 6 shown the change in purity of zinc powder with voltages that used $\mathrm{H}_{2} \mathrm{SO}_{4}$ solution with concentration $0.2 \mathrm{M}$, in these study six voltages used $(2,3,4,6,8$, and 11) this voltages effect on 
appearance density also and morphology of zinc powder, when the voltages increase the apparent density increase too, the purity increased first and beginning decrease in $8 \mathrm{v}$ and $11 \mathrm{v}$. The change in concentrations of $\mathrm{ZnSO}_{4} .7 \mathrm{H}_{2} \mathrm{O}$ when increased, the purity was decreased because there were impurities in powder inside zinc powder like iron and oxides, and the apparent density increased because of decrease of volume of particles that lead to full of the space between large particles by a small particles and depend on the relation between volume and apparent density in equation 1.1.

\subsection{Effect of voltages and concentrations changes on purity of zinc powder:}

The purity of zinc powder produced from galvanized sheet by electrodeposition method in acidic bath and precipitation by sulfuric acid was determined by X-Ray fluorescence spectrometer. In this study the electrolyte that used was mixture from $0.2 \mathrm{M}$ sulfuric acid and three different concentration of $\mathrm{ZnSO}_{4} \cdot 7 \mathrm{H}_{2} \mathrm{O}(50,75,100) \mathrm{M}$.

The highest purity obtained was 95.58 at $6 \mathrm{v}$ in $50 \mathrm{M}$ in stainless steel cathode. Because in this conditions acid solution dissolves zinc only and small amounts of other elements like iron, calcium, phosphorus, sulfur, and silicon from galvanized steel. The change in concentration of solution affected on purity which the increase of $\mathrm{ZnSO}_{4} \cdot 7 \mathrm{H}_{2} \mathrm{O}$ amount decreased the purity because increased it was increasing the dissolving of other impurities or elements. The values of purity in different concentrations are $(89.51,92.78$, and 95.48) for the same volte (2) v, in three concentrations $(50,75$, and 100) gm. / L respectively. The purities for 3 volt were $(88.30,87.86,85.33)$, the purities in 4 volt were $(90.03,89.23,86.52)$, the purities in 6 volt were $(95.58,92.02,88.09)$, in 8 volt the purities were (93.28, 91.10, and 81.91), and in 11 volt the purities were $(88.67,87.98$, and 84.95). The presence of Fe in the solution would decrease the purity of the $\mathrm{Zn}$ compound [19]. The effect of voltages has different effect on purity and in first range of voltages there was increased but when the voltage reach 8 Vand $11 \mathrm{v}$ there was decreased in purity because there was elements reduction in these voltages with zinc powder this effect shown in the figure 6 .

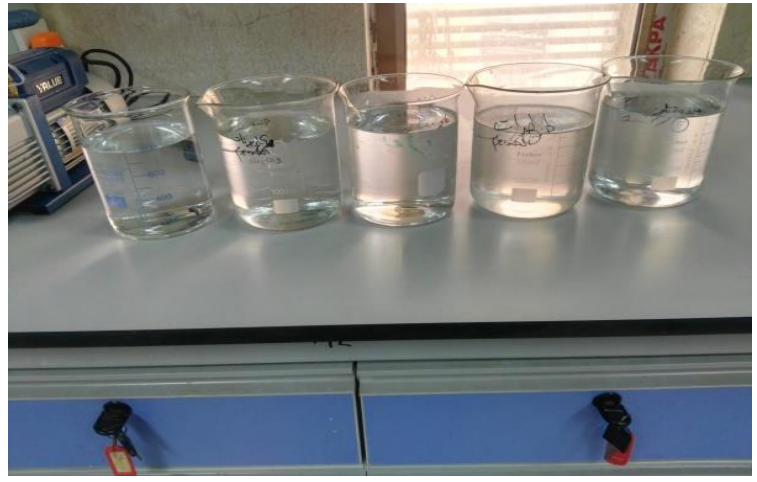

Figure 4 shows the washing process of cathode.

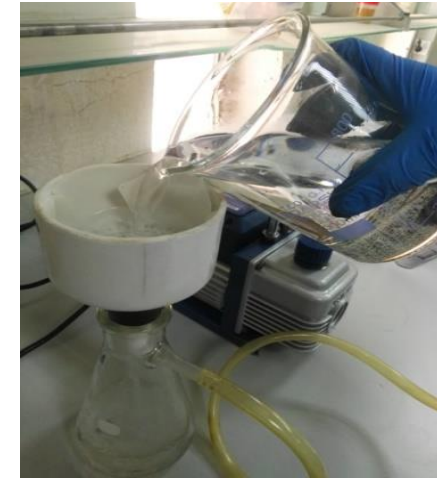

Figure 5 shows the filtration process. 


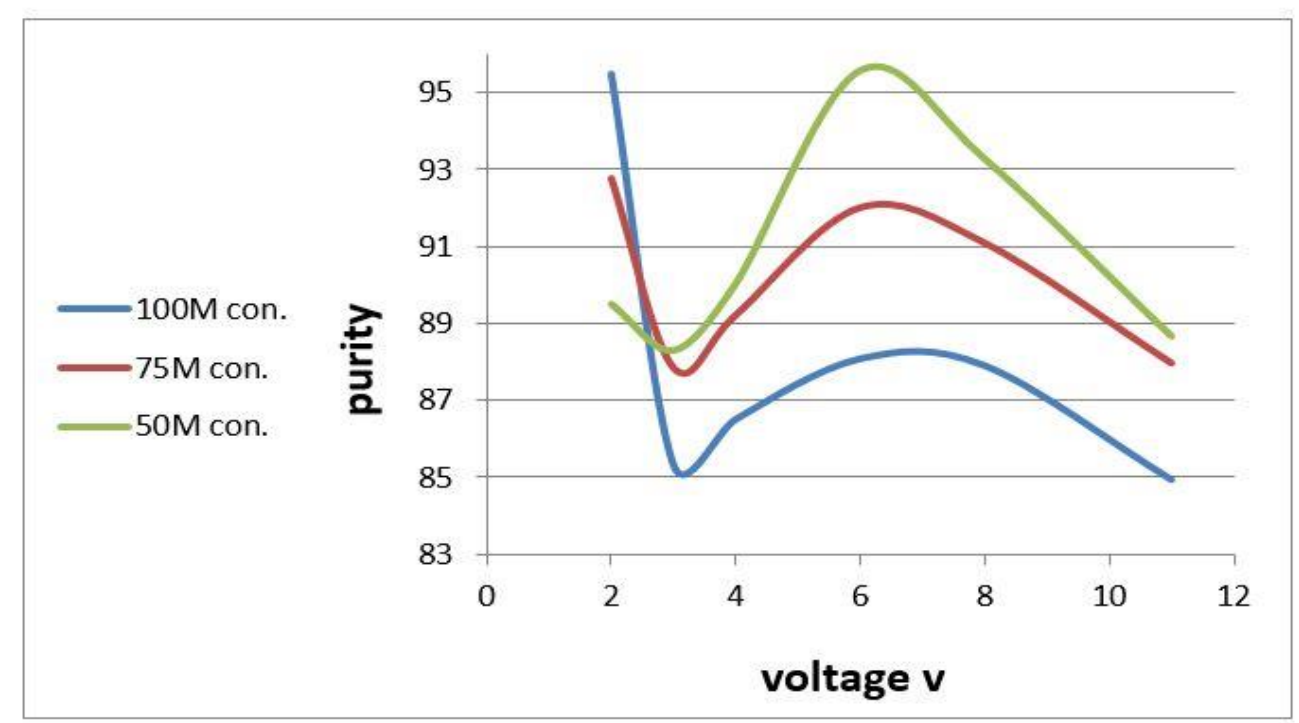

Figure 6: Effect of change in voltages on the purity with change of zinc ion concentrations.

In this case when voltage was $3 \mathrm{~V}$ there was iron in results of XRF analysis and some another elements this impurities made purity decrease also it may be return to washing process so when we increase the time of washing we can remove the impurities that attached on cathode, in $11 \mathrm{~V}$ the iron was also deposited on cathode inside zinc but in $6 \mathrm{~V}$ the purity of zinc powder was highest because a small amount of impurities was deposited on stainless steel cathode.

\subsection{Effect of voltages and concentrations changes on apparent density of zinc powder.}

The apparent density increase with increasing of zinc ion concentrations that the size of particles will decrease related to the relationship between the size of particles and apparent density that is reverse which determined by equation of apparent density and the figure 7 show the relationship between the apparent density and zinc ion concentrations in stainless steel cathode. But the effect of voltages is when the voltages increased, the volume of particles will increase too that leads to decrease the apparent density because the particle size distribution increased due to the small particles trap between the large particles and in order to the equation of apparent density the relationship between volume and the apparent density was reverse these effects shown in figures 8, 9, 10 .

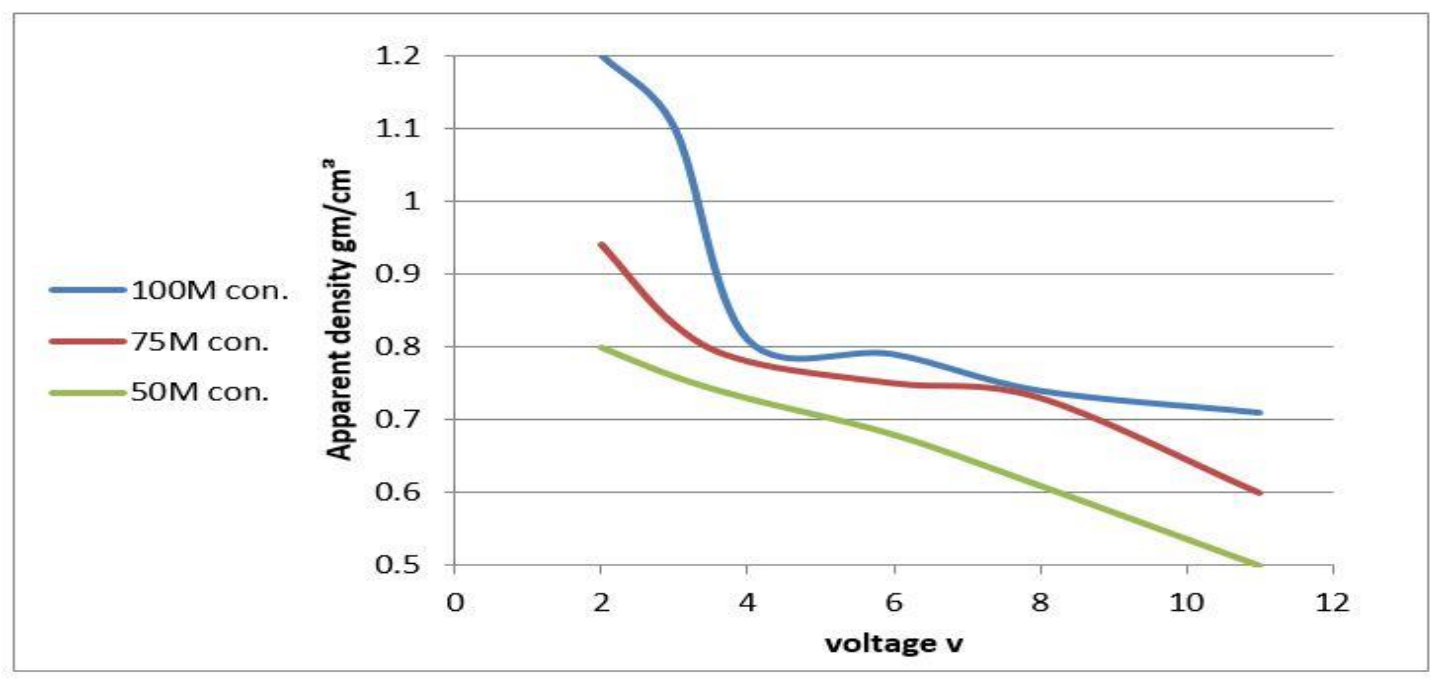

Figure 7: shows the relationship between apparent densities and zinc ion concentrations. 


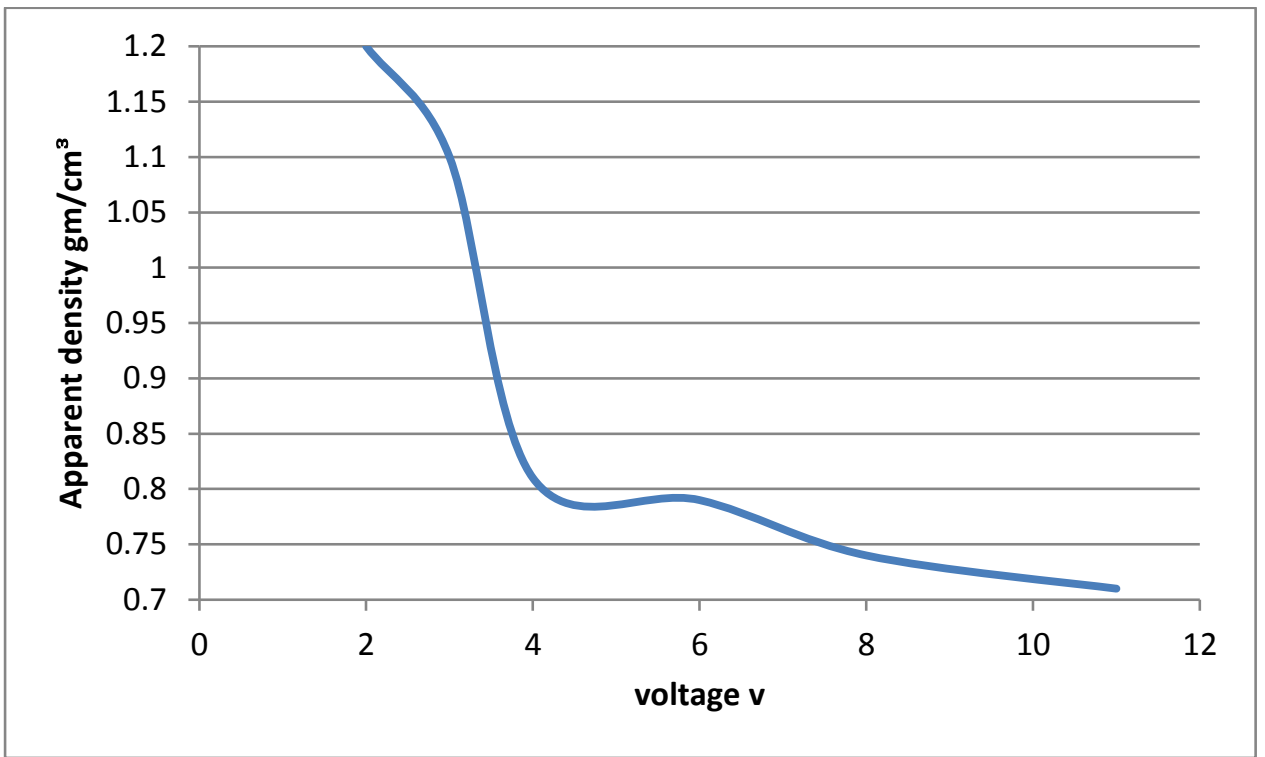

Figure 8: shows the effect of change in voltages on the apparent density in the 100M zinc ion concentration.

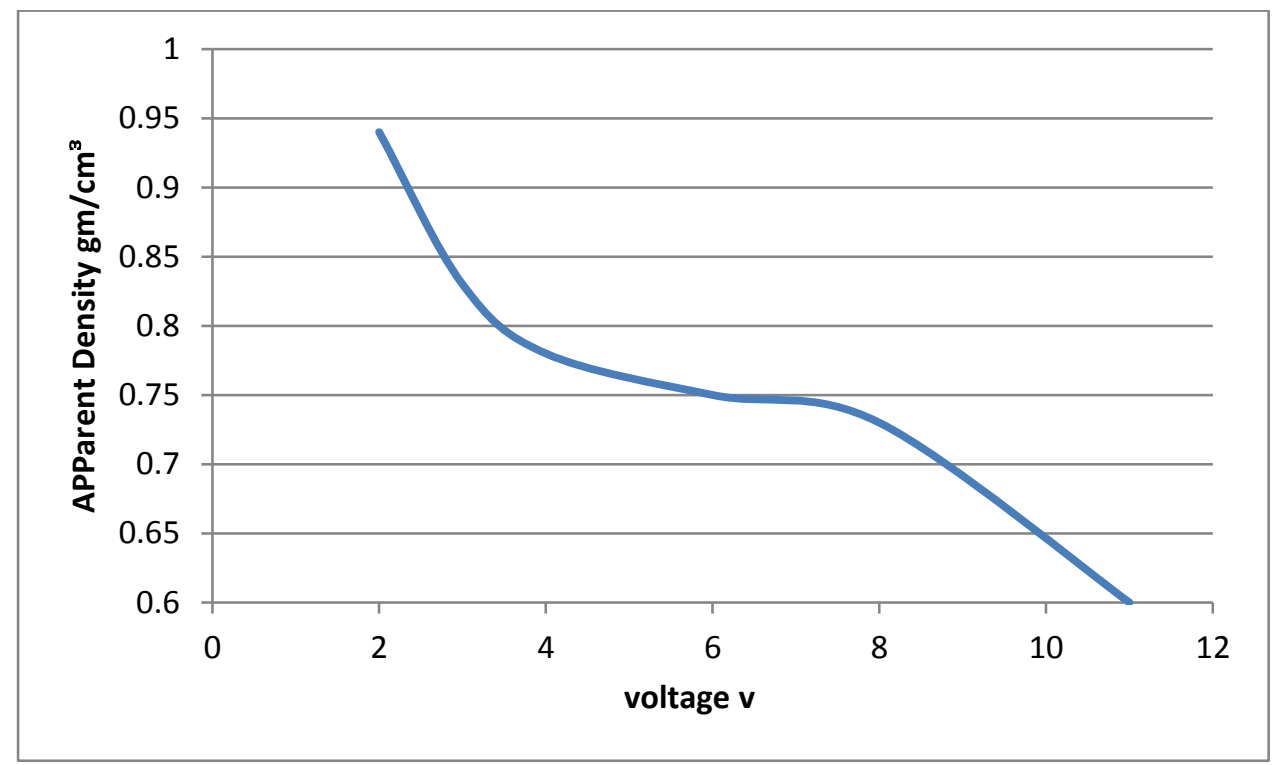

Figure 9: shows the effect of change in voltages on the apparent density in the $75 \mathrm{M}$ zinc ion concentration. 


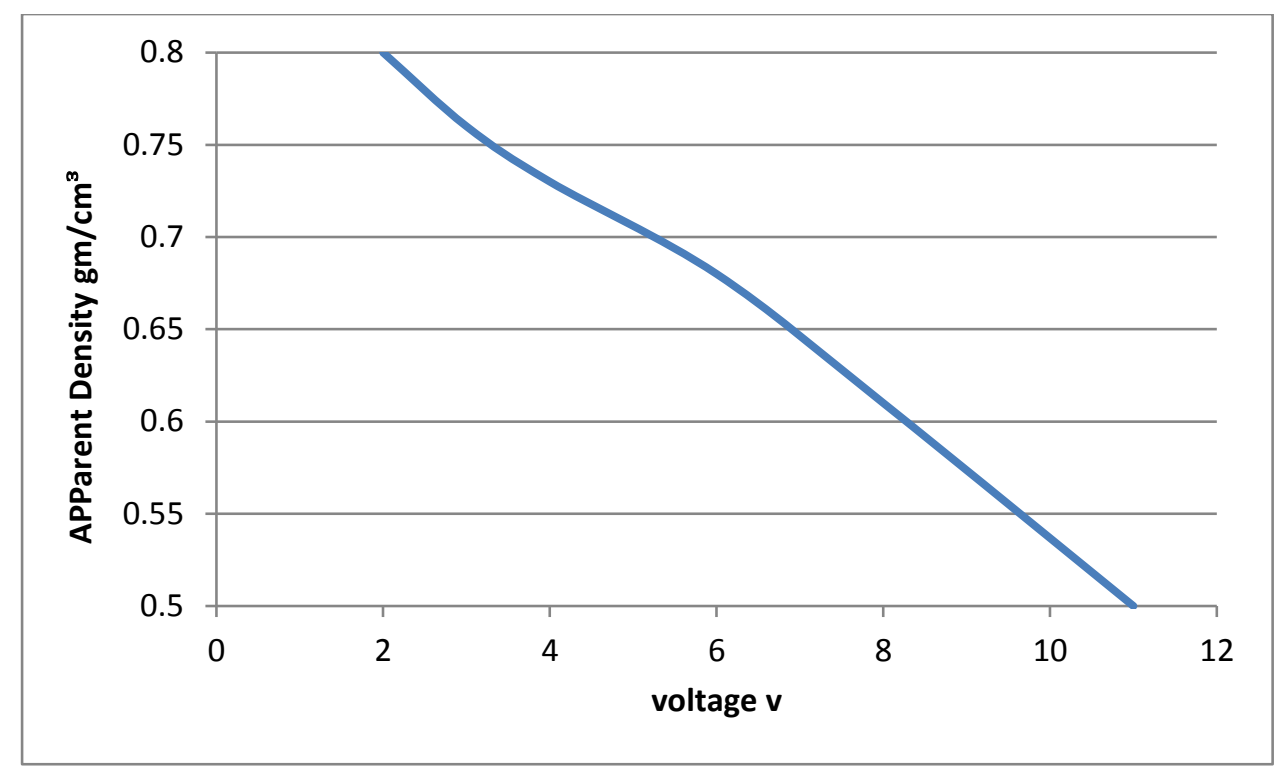

Figure10: shows the effect of change in voltages on the apparent density in the 50M zinc ion concentration.

\section{5 morphology of zinc powder by optical microscopy and SEM analysis:}

Figure 11 shows the effect of concentration of $\mathrm{ZnSO}_{4} \cdot 7 \mathrm{H}_{2} \mathrm{O}$ on the morphology of zinc powder in stainless steel cathode by SEM at $6 \mathrm{~V}$ in (a: $100 \mathrm{M}$, b: $75 \mathrm{M}$ and c: $50 \mathrm{M}$ ). The SEM was used to see the details of zinc powders. Figure 12 shows the effect of concentration of $\mathrm{ZnSO}_{4} \cdot 7 \mathrm{H}_{2} \mathrm{O}$ on the morphology of zinc powder in stainless steel cathode by SEM at $8 \mathrm{~V}$ in a: $100 \mathrm{M}$, b: $75 \mathrm{M}$, and c: 50 . The general shape for all particles in all experiments is dendrite due to the release of hydrogen gas at the surface of the cathode, where a small part of it enters the structure of the powder layer and makes it irregular in nature, making the particles grow dendritic. cathode.

The figure 13 shows the effect of voltages on the morphology of zinc powder in stainless steel
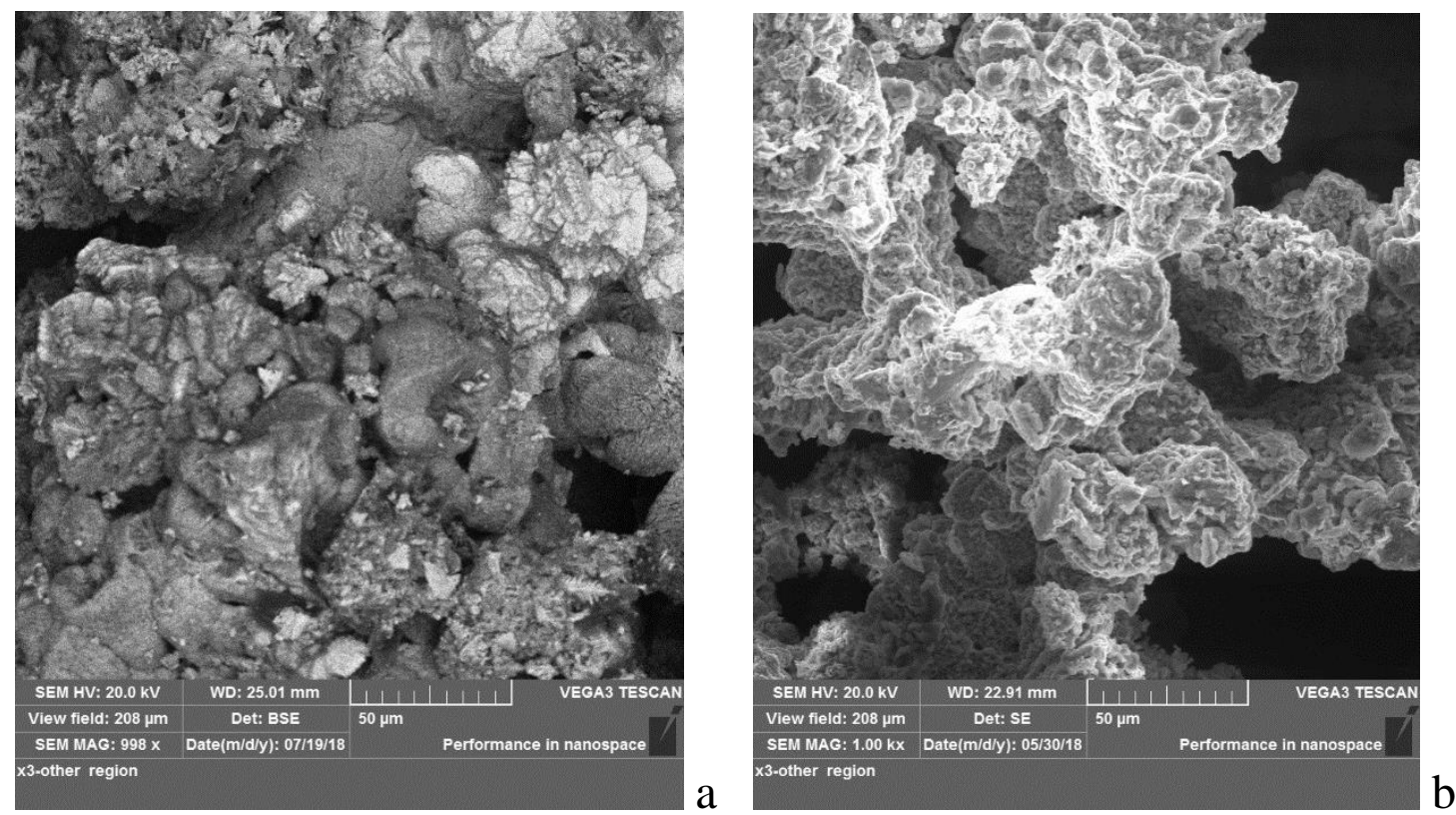
C

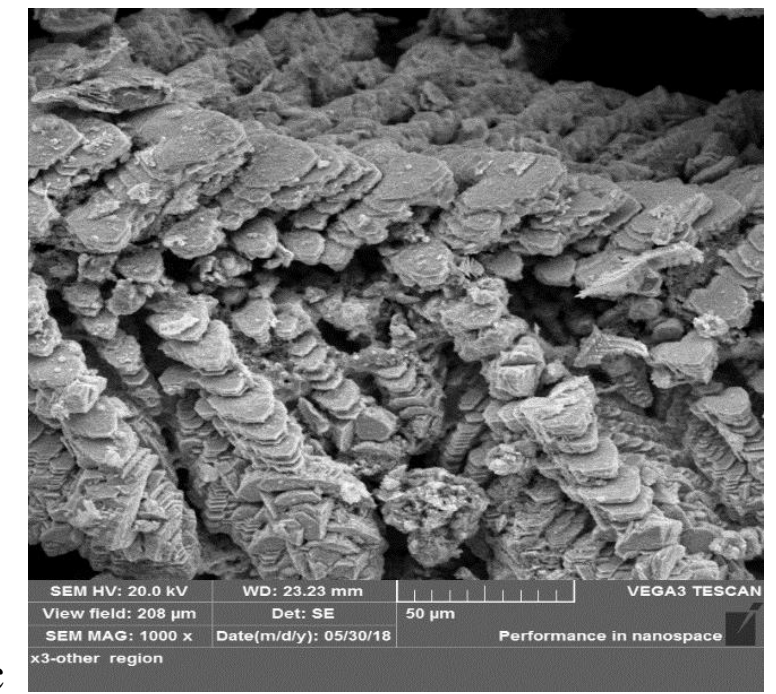

Figure 11: shows the effect of concentration of $\mathrm{ZnSO}_{4} \cdot 7 \mathrm{H}_{2} \mathrm{O}$ on the morphology of zinc powder in stainless steel cathode by SEM at $6 \mathrm{~V}$ in (a: $100 \mathrm{M}$, b: $75 \mathrm{M}$ and c: $50 \mathrm{M}$ ).
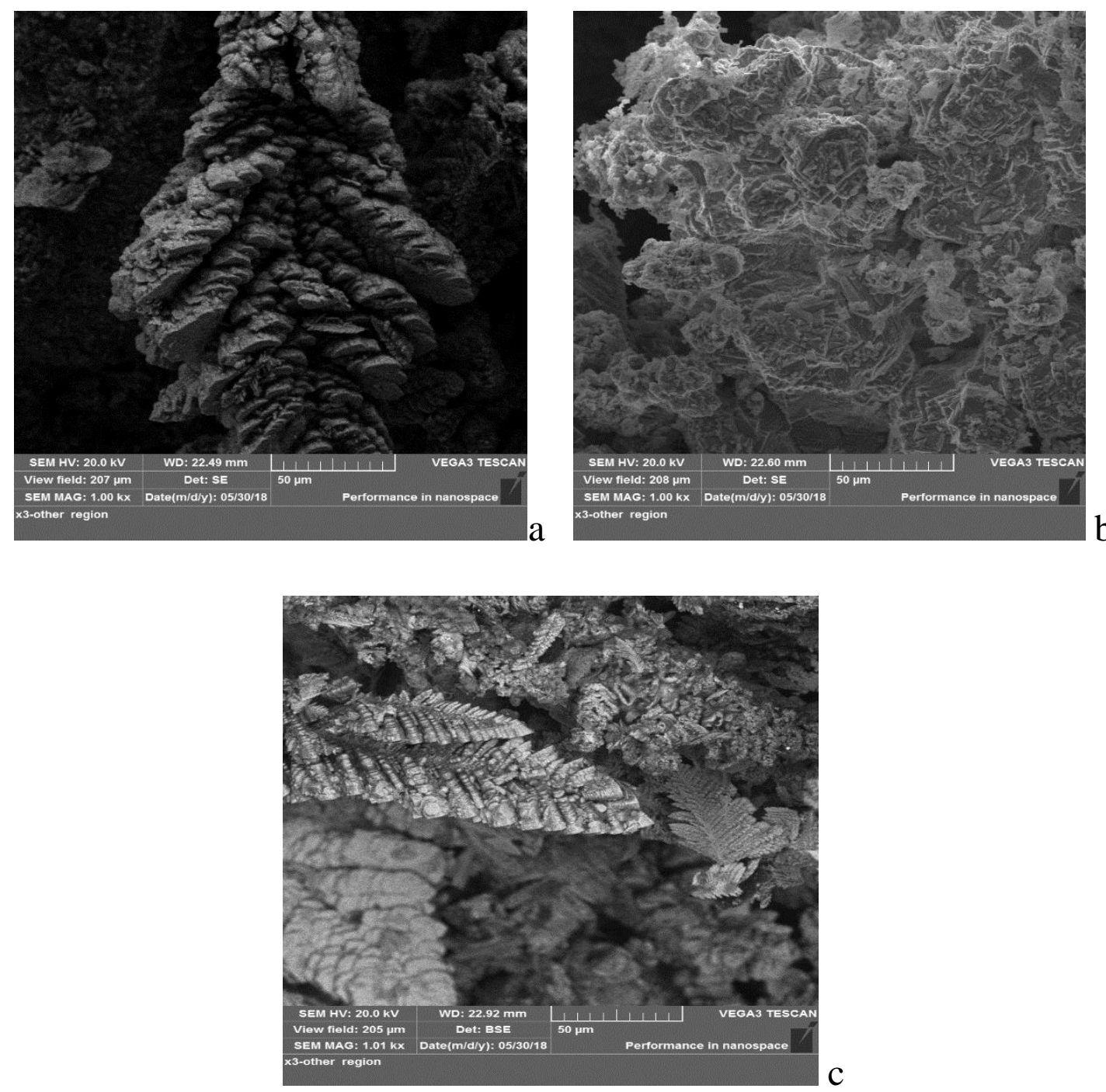

Figure 12: shows the effect of concentration of $\mathrm{ZnSO}_{4} .7 \mathrm{H}_{2} \mathrm{O}$ on the morphology of zinc powder in stainless steel cathode by SEM at $8 \mathrm{~V}$ in a: $100 \mathrm{M}$, b: $75 \mathrm{M}$, and c: 50 . 

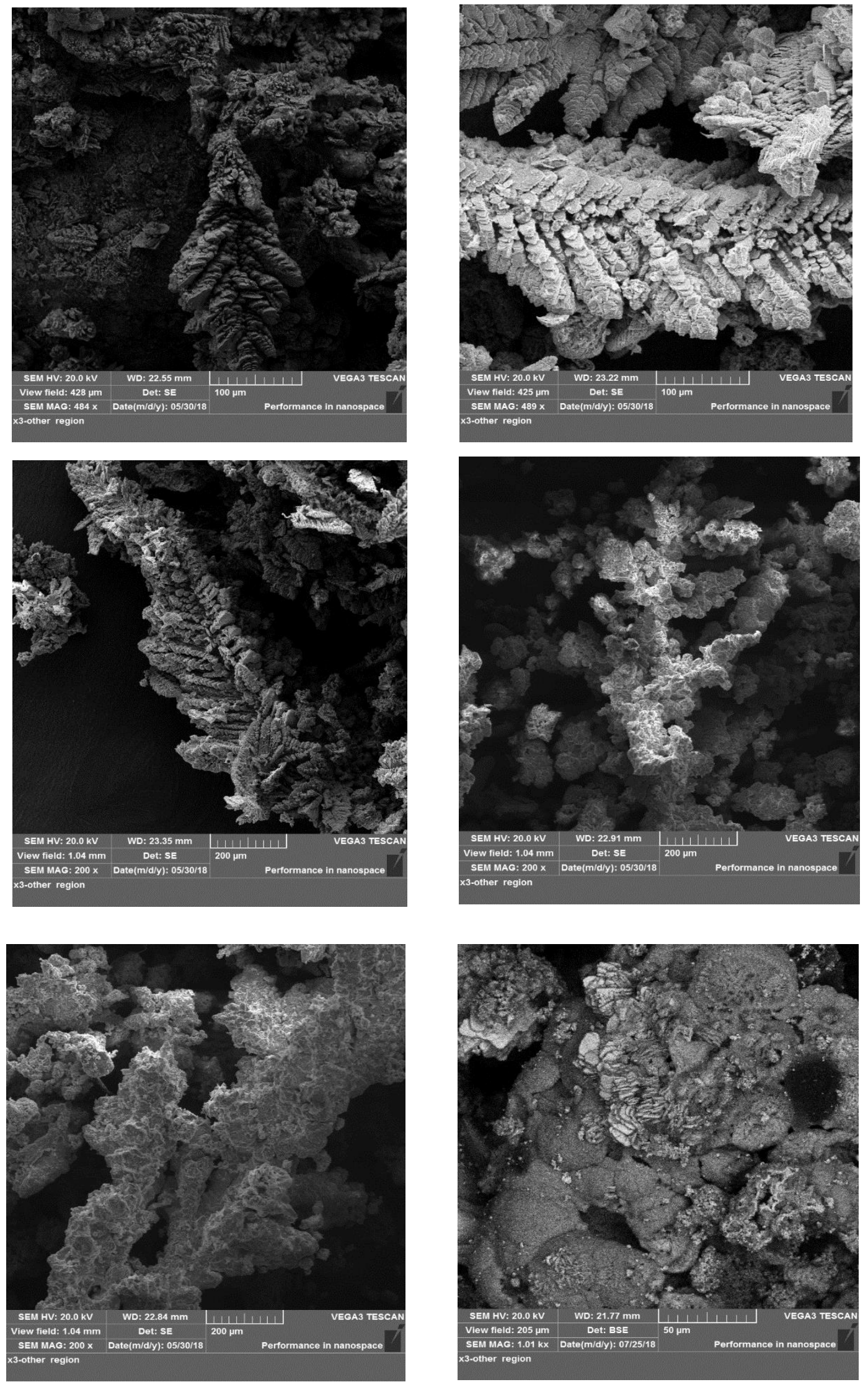

Figure 13: shows the effect of different voltages on morphology of zinc powder by SEM. 


\section{Conclusions:}

The increased of zinc ion concentration was decreased the purity of $\mathrm{Zn}$ powder, the apparent density was increase too, were $(0.80,0.90$, and 1.2$)$ in $2 \mathrm{~V}$ from $(50,75$, and 100$) \mathrm{M}$ respectively. Six different voltages used $(2,3,4,6,8$, and 11) V, for the same concentration 50M, the purities $(89.51$, $88.30,90.04,95.58,93.28$ and 88.67) and their apparent densities were $(0.80,0.76,0.73,0.68,0.61$ and $0.50 \mathrm{gm} . / \mathrm{cm}^{3}$ ) respectively, that the increased of voltages from $2 \mathrm{~V}$ to $11 \mathrm{~V}$ was decrease the apparent density from $0.80 \mathrm{gm} . / \mathrm{cm}^{3}$ to $0.50 \mathrm{gm} . / \mathrm{cm}^{3}$.

The highest purity of $\mathrm{Zn}$ powder that obtained from this study was 95.58 in $6 \mathrm{~V}$, and the morphology of zinc powder that produced from electrodeposition of galvanized steel is dendritic for all experiments.

\section{CONFLICT OF INTERESTS.}

- There are no conflicts of interest.

\section{References}

[1] Kaur, Kuljeet, Rajiv Gupta, Shubhini A. Saraf, and Shailendra K. Saraf. "Zinc: the metal of life." Comprehensive Reviews in Food Science and Food Safety 13, no. 4, 2014: 358-376.

[2] Energy and Environmental profile of the U.S. mining industry, "Lead and Zinc" U.S. department of interior, U.S. geological survey, mineral commodity summary, zinc, Available online at http://energy.gov/sites/prod/files/2013/11/f4/lead_zinc.pdf, 2001.

[3] Jha, Manis K., Vinay Kumar, and R. J. Singh. "Review of hydrometallurgical recovery of zinc from industrial wastes." Resources, conservation and recycling 33, no. 1, 2001: 1-22.

[4] Novotny, Thomas E., Kristen Lum, Elizabeth Smith, Vivian Wang, and Richard Barnes. "Cigarettes butts and the case for an environmental policy on hazardous cigarette waste." International journal of environmental research and public health 6, no. 5, 2009: 1691-1705.

[5] Tchounwou, Paul B., Clement G. Yedjou, Anita K. Patlolla, and Dwayne J. Sutton. "Heavy metal toxicity and the environment." In Molecular, clinical and environmental toxicology, pp. 133-164. Springer, Basel, 2012.

[6] American Galvanizers Association, "Zinc Coatings”, available in, www.galvanizeit.org, 2011.

[7] Gerberding, J. L. "Toxicological profile for zinc." Atlanta: US Department of Health and Human Services, Agency for Toxic Substances and Disease Registry, 2005: 11-118. Available online at http://www.atsdr.cdc.gov/toxprofiles/tp60.pdf.

[8] Bright, Mark A., Nathan J. Deem, and John Fryatt. "The advantages of recycling metallic zinc from the processing wastes of industrial molten zinc applications." Light Metals, 2007: 101-109.

[9] Abkhoshk, E., E. Jorjani, M. S. Al-Harahsheh, F. Rashchi, and M. Naazeri. "Review of the hydrometallurgical processing of non-sulfide zinc ores." Hydrometallurgy 149, 2014: 153-167.

[10] Li, Cun-Xiong, Hong-Sheng Xu, Zhi-Gan Deng, Xing-Bin Li, Ming-Tin Li, and W. E. I. Chang. "Pressure leaching of zinc silicate ore in sulfuric acid medium." Transactions of Nonferrous Metals Society of China 20, no. 5, 2010: 918-923.

[11] Kuhn, Howard, ed. Powder metallurgy processing: the techniques and analyses. Elsevier, 2012.

[12] Groover, Mikell P. Fundamentals of Modern Manufacturing: Materials, Processes, and Systems. John Wiley \& Sons, 2010.

[13] Anil Kumar Sinha, "Powder Metallurgy", 1987.

[14] Gamburg, Yuliy D., and Giovanni Zangari. "Thermodynamics and Kinetics of Nucleation." In Theory and Practice of Metal Electrodeposition, pp. 97-122. Springer, New York, NY, 2011.

[15] Paunovic, Milan, and Mordechay Schlesinger. Fundamentals of electrochemical deposition. Vol. 45. John wiley \& sons, 2006. 
[16] Pan, Junli, Yuehua Wen, Jie Cheng, Junqing Pan, Zhangli Bai, and Yusheng Yang. "Zinc deposition and dissolution in sulfuric acid onto a graphite-resin composite electrode as the negative electrode reactions in acidic zinc-based redox flow batteries." Journal of Applied Electrochemistry 43, no. 5, 2013: 541-551.

[17] AÇMA, ERCAN, and SERDAR AKTAŞ. "Recovery of zinc from galvanized scraps." Turkish Journal of Engineering and Environmental Sciences 26, no. 5, 2002: 395-402.

[18] Schlesinger, Mordechay, and Milan Paunovic, eds. Modern electroplating. Vol. 55. John Wiley \& Sons, 2011

[19] Aydin, A. "Recovery of Zinc and Lead from Cinkur Leach Resudies by using Hydrometallurgical Techniques." PhD diss., Thesis submitted to the Graduate School of Natural and Applied Sciences of Middle East Technical University, Turkey, 2007. 


\section{رقية هشام عبد الستار رابحة صالح ياسين فراس فرحان سيد \\ قسم هندسة الإنتاج و المعادن، الجامعة النكنولوجية، بغداد - العراق \\ qanoonyhisham@yahoo.com}

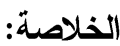

في هذا البحث تم در اسة تأثثر الفولتية وتركيز المحلول على خصائص مسحوق الخارصين (النقاوة، الثنكل الحيبي، الكثافة الظاهرية) الناتجة من النفايات الصناعية (الفو لاذ المجلفن) في عملية النحليل الكهربائي، يستخدم حامض الكبريتيك تركيز 0.2 مو لاري وكبريتات الزنك المائية

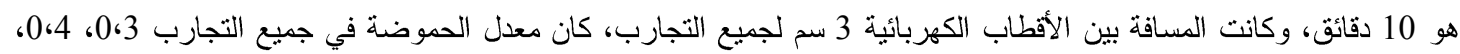

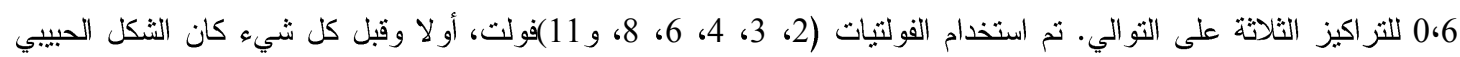

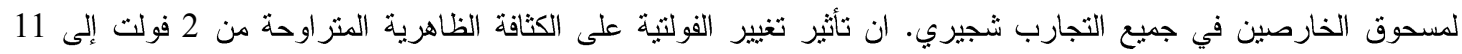

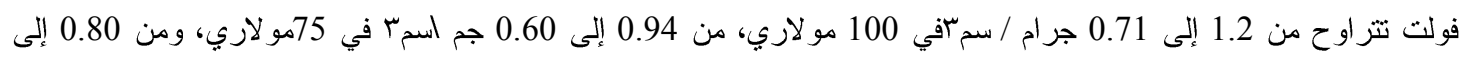
0.50 جم اسم في ثركيز 50 مو لاري. بينما تزدداد النقاوة بانخفاض تركيز أيونات الخارصين (10.71 (89.51، تر اكيز مختلفة من نفس الجهد 2 فولت. ان أعلى نقاوة لمسحوق الخارصين كانت 95.58 في 6 فولت من التزكيز 50 مولاري. لاري. الكلمات الدالة: الخارصين، الفو لاذ المجلفن، عملية التحليل الكهربائي، حامض الكبريتيك، النقاوة، والكثافة الظاهرية. 